\title{
PENERAPAN MODEL PEMBELAJARAN BERBASIS PENGALAMAN UNTUK MENINGKATKAN PEMAHAMAN KONSEP SISWA
}

\author{
Irwan Muhammad Ridwan' ${ }^{\text {Rahmat Rizal' }}$ \\ 1,2. Program Studi Pendidikan Fisika, FKIP, Universitas Siliwangi, Jalan SIliwangi No 24 , \\ Tasikmalaya, 46115, Indonesia \\ 1. E-mail: irwanmr@unsil.ac.id
}

\begin{abstract}
ABSTRAK
Telah dilakukan penelitian eksperimen semu tentang penerapan model pembelajaran berbasis pengalaman untuk meningkatkan pemahaman konsep materi pokok kalor siswa SMP. Sampel penelitian ini siswa kelas tujuh di salah satu SMP di Tasikmalaya dengan desain penelitian Randomized Control Group Pretest-Posttest Desig. Instrumen yang digunakan meliputi tes pemahaman konsep yang mencakup aspek translasi, interpretasi, dan ekstrapolasi, angket tanggapan siswa. Kelompok eksperimen menerima model pembelajaran berbasis pengalaman sedangkan kelas kontrol menerima pembelajaran konvensional. Hasil penelitian menunjukan bahwa pemahaman konsep siswa meningkat dengan kategori sedang dengan rata-rata gain yang dinormalisasi 0,52 untuk kelas eksperimen sedangkan kelas kontrol mengalami peningkatan kategori sedang dengan rata-rata gain yang dinormalisasi 0,41 . Hasil uji statistik (Uji-t) menunjukan bahwa penerapan model pembelajaran berbasis pengalaman secara signifikan dapat meningkatkan pemahaman konsep dibandingkan dengan pembelajaran konvensional. Siswa memberikan tanggapan positif terhadap penerapan model pembelajaran berbasis pengalaman dengan nilai sebesar 93\%.
\end{abstract}

Kata kunci: pembelajaran berbasis pengalaman, pemahaman konsep

\begin{abstract}
It has been done the research of illusion experiment about the implementation experience-based learning (EBL) to improve the results of concept comprehension in the topic of heat. A sample of this research was student at the seventh grade at one of junior high school in Tasikmalaya in year 2012/2013 with a randomized control group pretestposttest design. The instrument used concept comprehension test include the translation, interpretation, and extrapolation and questionare. The experiment group received EBL while the control group received conventional learning. The result of this research show that the comprehension of students' concept increase with medium category in average of normalized gain is 0,52 for the experiment class while control class get the increasing of medium category with average of normalized gain is 0,41 . The results of statistics test (t-test) show that implementation EBL can improve concept comprehension significantly compared with conventional learning. The students give positive response toward the implementation of EBL was $93 \%$.
\end{abstract}

Keywords: experience-based learning, concept comprehension,

Received: 30 November 2018 ; Accepted: 1 Februari 2019 ; Published: 4 Februari 2019 


\section{PENDAHULUAN (CAMBRIA, ALL CAPS, 12 PT, BOLD)}

Salah satu tujuan pelajaran IPA adalah agar siswa menguasai berbagai konsep dan prinsip IPA untuk mengembangkan pengetahuan, keterampilan, dan sikap percaya diri sehingga dapat diterapkan dalam kehidupan sehari-hari. Pengajaran fisika juga dimaksudkan untuk pembentukan sikap yang positif terhadap fisika, yaitu merasa tertarik untuk mempelajari fisika lebih lanjut karena merasakan keindahan dalam keteraturan perilaku alam serta kemampuan fisika dalam menjelaskan berbagai peristiwa alam dan penerapan fisika dalam teknologi.

Untuk mencapai tujuan tersebut, proses belajar mengajar yang dilakukan oleh guru perlu direncanakan dan dilakukan dengan sebaikbaiknya. Tugas guru bukan hanya mengajar, tapi lebih kepada proses membelajarkan siswa. Belajar dapat dipandang sebagai proses yang diarahkan untuk mencapai tujuan dan proses berbuat melalui berbagai pengalaman belajar yang dirancang dan dipersiapkan guru. Pengalaman belajar yang dimaksud adalah pengalaman belajar yang diperoleh pancaindra yang diolah oleh kreasi pemikiran siswa. Proses belajar merupakan proses melihat, mengamati dan memahami sesuatu yang ada di sekitar siswa.

(Ratna Wilis Dahar, 1996) menyatakan bahwa salah satu keluhan dalam dunia pendidikan khususnya pendidikan IPA adalah siswa hanya diajarkan untuk menghapal tanpa memahami benar isi pelajaran, termasuk didalamnya mata pelajaran fisika. Hal ini menyebabkan siswa mudah lupa dan tidak bisa menghubungkan satu konsep dengan konsep yang lain.

Hal ini diperkuat oleh hasil (Mathematics, 2011) yang menunjukan bahwa nilai rata-rata matematika siswa kelas VIII menempati urutan ke-38 dari 46 negara. Hasil sains tak kalah mengecewakan, Indonesia diurutan ke-40 dari 42 negara. Rendahnya kemampuan siswa Indonesia dalam mata pelajaran sains juga tercermin dalam Program for International Student Assesment (PISA) yang mengukur kecapan anak-anak berusia 15 tahun dalam implementasi pengetahuan yang dimiliki untuk menyelesaikan masalah-masalah dunia nyata. Indonesia telah ikut dalam siklus tiga tahunan penilaian tersebut, yaitu tahun 2003, tahun 2006, dan tahun 2009. Hasilnya sangat memprihatinkan. Siswa-siswi Indonesia berada di peringkat bawah.

Selain permasalahan yang telah dipapakan, fisika sebagai salah satu bagian IPA di sekolah menengah pertama (SMP) sering dianggap oleh siswa sebagai salah satu pelajaran yang tidak menarik, sehingga seringkali siswa mempunyai sikap yang negatif terhadap pelajaran fisika. Hal ini senada dengan yang diungkapkan oleh (J Yurneti, 2002) :

Fisika merupakan salah satu cabang sains yang diajarkan di tingkat pendidikan dasar dan menengah dan salah satu mata pelajaran yang ditakuti oleh peserta didik. Padahal, mata pelajaran fisika itu sebenarnya menarik dan dekat dengan kehidupan. Oleh sebab itu perlu penerapan metode, strategi dan model yang bervariasi dalam pembelajaran fisika, sehingga sisiwa tidak menganggap fisika adalah suatu yang perlu ditakuti.

(S.B. Djamarah, 2009) menyebutkan bahwa belajar sambil melakukan (learning by doing) lebih mendatangkan hasil bagi anak didik, sebab kesan yang tersimpan dalam benak anak didik akan lebih bertahan lama. Selain belajar untuk melakukan, kegiatan pembelajaran pun harus diarahkan untuk memberdayakan semua potensi pesera didik untuk menguasai kompetensi yang diharapkan. Kegiatan pembelajaran mengembangkan kemampuan untuk mengetahui, memahami, melakukan sesuatu. Dengan demikian, proses pembelajaran perlu memperhatikan hal-hal sebagai berikut: 1) berpusat pada peserta didik (Student centered), 2) mengembangkan aktivitas dan kreatifitas peserta didik, 3) menciptakan situasi dan kondisi yang menyenangkan dan menantang, 4) bermuatan nilai, etika, estetika, logika, dan kinestetika, dan 5) menyediakan pengalaman belajar yang dapat mengembangkan kemampuan konsep dan keterampilan proses siswa.

Dalam konsep-konsep tertentu pengalaman siswa atau fenomena yang dialami siswa dapat 
dimanfaatkan guru untuk membantu proses belajar mengajar. Fenomena tersebut dapat dimanfaatkan oleh guru dalam rangka meningkatkan pemahaman konsep dan keterampilan proses sains siswa, yaitu melalui pembelajaran yang menekankan pada pengalaman belajar di kelas dengan mengacu pada pengalaman yang sering terjadi dan dialami oleh siswa sehingga siswa belajar menemukan sendiri konsep yang dipelajarinya. Hal ini didasarkan pada kenyataan bahwa siswa sering mengalami kesulitan dalam memahami suatu konsep karena guru tidak menghubungkan apa yang dipelajari dengan pengalaman yang sering dijumpai siswa.

Berdasarkan data yang diperoleh dari hasil observasi awal di sekolah tempat penelitian, nilai rata-rata ulangan harian IPA kurang dari 30\% yang mencapai KKM. Menurut pendapat peneliti, hal tersebut disebabkan proses pembelajaran yang masih bersifat konvensional dimana siswa hanya diberikan informasi tanpa diberi peran aktif dan kurang terlibat dalam proses pembelajaran dalam arti bahwa siswa hanya sebagai "pendengar yang baik" dalam proses pembelajaran. Selan itu, guru pun kurang memanfaatkan kejadian alam ataupun fenomena fisika yang sering terjadi untuk dijadikan bahan ataupun sarana dalam menunjang keantusiasan siswa dalam pembelajaran.

Model pembelajaran berbasis pengalaman ini dikembangkan dari suatu model pembelajaran berbasis masalah (PBM) yang merupakan bagian dari pembelajaran kontekstual. Pengalaman siswa yang dijadikan dasar pengamatan berupa fenomena yang sering dialami siswa dalam kehidupan sehari-hari. Pengalaman tersebut dijadikan bahan kajian dalam proses pembelajaran sehingga pembelajaran yang dilaksanakan bersifat kontekstual dan dekat dengan apa yang sering dialami siswa.

Materi fisika yang digunakan dalam penelitian ini adalah konsep kalor. Pemilihan konsep kalor sebagai materi yang diteliti dikarenakan konsep tersebut banyak materi/konsep yang berkaitan dengan kejadian yang sering dilihat, dirasakan, dan dialami oleh siswa dalam kehidupan sehari-hari namun siswa sering mengalami kesulitan dalam memahami kejadian-kejadian yang berkaitan dengan konsep kalor tersebut.

Berdasarkan permasalahan yang dipaparkan, peneliti mencoba untuk melakukan penelitian dengan menerapkan suatu model yang menjadikan pengalaman siswa sebagai sarana dalam memahami suatu konsep. Judul yang akan diajukan dalam penelitian ini adalah "Penerapan model pembelajaran berbasis pengalaman untuk meningkatkan pemahan konsep dan keterampilan proses sains siswa”.

\section{METODE PENELITIAN}

Metode penelitian yang digunakan adalah metode kuasi eksperimen dan metode deskriptif, metode kuasi eksperimen digunakan untuk mengetahui perbandingan peningkatan pemahaman konsep dan keterampilan proses sains siswa yang menggunakan model pembelajaran berbasis pengalaman dengan model pembelajaran konvensional. Desain penelitian yang digunakan adalah Randomized Control Group Pretest-Posttest Design (Sugiyono, 2009).

Tabel 1. Desain Penelitian

\begin{tabular}{ccc}
\hline Pretest & Perlakuan & Posttest \\
\hline $\mathrm{O}_{1}$ & $\mathrm{X}_{1}$ & $\mathrm{O}_{2}$ \\
$\mathrm{O}_{3}$ & $\mathrm{X}_{2}$ & $\mathrm{O}_{4}$ \\
\hline
\end{tabular}

Penelitian ini dilaksanakan pada dua kelas yaitu satu kelas eksperimen dan satu kelas kontrol, diawali dengan memberikan pretest untuk mengidentifikasi kemampuan awal siswa. Kemudian dilaksanakan pembelajaran dengan menggunakan model pembelajaran berbasis pengalaman. Setelah pembelajaran selesai dilakukan posttest untuk mengidentifikasi peningkatan pemahaman konsep dan keterampilan proses sains siswa. Metode deskriptif digunakan untuk mendeskripsikan tanggapan siswa terhadap penggunaan model pembelajaran berbasis pengalaman. 
Selanjutnya, langkah-langkah model pembelajaran berbasis pengalaman dalam penelitian ini dapat dilihat pada tabel 1 sebagai berikut:

Tabel 2. Sintaks model Pembelajaran Berbasis

Pengalaman (Kaniawati, 2011)

\begin{tabular}{|c|c|}
\hline $\begin{array}{c}\text { Tahapan } \\
\text { Pembelajaran }\end{array}$ & Aktivitas Guru \\
\hline $\begin{array}{c}\text { Fase } 1 \\
\text { Orientasi siswa } \\
\text { pada } \\
\text { pengalaman } \\
\text { nyata }\end{array}$ & $\begin{array}{c}\text { Melakukan apersepsi } \\
\text { Memotivasi siswa untuk fokus } \\
\text { pada pembelajaran } \\
\text { Menyajikan peristiwa, } \\
\text { kejadian, fenomena fisis yang } \\
\text { sering dialami siswa dalam } \\
\text { keseharian } \\
\text { Menjelaskan tujuan dan } \\
\text { kompetensi yang hendak } \\
\text { dicapai melalui pembelajaran }\end{array}$ \\
\hline $\begin{array}{c}\text { Fase } 2 \\
\text { Penyajian model } \\
\text { dari peristiwa } \\
\text { dan fenomena } \\
\text { fisis yang dialami } \\
\text { siswa } \\
\end{array}$ & $\begin{array}{c}\text { Mengorganisasikan siswa ke } \\
\text { dalam kelompok kecil } \\
\text { Menyajikan model dari } \\
\text { pengalaman fisis yang ditinjau }\end{array}$ \\
\hline $\begin{array}{c}\text { Fase } 3 \\
\text { Penanaman } \\
\text { konsep melalui } \\
\text { pemberian } \\
\text { pengalaman } \\
\text { langsung melalui } \\
\text { inkuiri sains }\end{array}$ & $\begin{array}{c}\text { Melakukan demonstrasi untuk } \\
\text { mengarahkan siswa dalam } \\
\text { mengidentifikasi konsep- } \\
\text { konsep yang tercakup dalam } \\
\text { peristiwa fisis yang dialami } \\
\text { (pengantar ke arah } \\
\text { penyelidikan) } \\
\text { Membagikan LKS penyelidikan } \\
\text { Memberikan penjelasan } \\
\text { mengenai hal-hal yang perlu } \\
\text { diperhatikan dalam proses } \\
\text { penyelidikan } \\
\text { Membimbing siswa dalam } \\
\text { dalam melakukan } \\
\text { penyelidikan secara inkuiri } \\
\text { melalui panduan LKS, hingga } \\
\text { didapatkan kesimpulan } \\
\text { Memfasilitasi kelompok siswa } \\
\text { untuk mengkomunikasikan } \\
\text { dan mendiskusikan hasil-hasil } \\
\text { penyelidikan dengan } \\
\text { kelompok lain }\end{array}$ \\
\hline
\end{tabular}

\begin{tabular}{|c|c|}
\hline $\begin{array}{c}\text { Fase 4 } \\
\text { Penjelasan fisis } \\
\text { dari peristiwa } \\
\text { atau kejadian } \\
\text { yang dialami } \\
\text { siswa }\end{array}$ & $\begin{array}{c}\text { Meminta siswa untuk } \\
\text { menjelaskan fenomena yang } \\
\text { disajikan di fase-1 }\end{array}$ \\
\hline $\begin{array}{c}\text { Fase 5 } \\
\text { Penguatan dan } \\
\text { tindak lanjut } \\
\text { belajar }\end{array}$ & $\begin{array}{c}\text { Memberikan penguatan } \\
\text { konsep } \\
\text { berupa contoh soal } \\
\text { Memfasilitasi tindak lanjut } \\
\text { belajar melalui pemberian } \\
\text { tugas terstruktur }\end{array}$ \\
\hline
\end{tabular}

Subjek penelitian adalah siswa kelas VII pada salah satu SMP di Kabupaten Tasikmalaya yang terdiri dari tiga kelas. Sampel penelitian yaitu dua kelas yang dipilih secara cluster random sampling. Untuk pengumpulan data penelitian telah dibuat instrumen penelitian berupa tes pemahaman konsep, dan tes keterampilan proses sains dalam bentuk pilihan ganda. Selain itu, juga digunakan angket untuk mengetahui tanggapan siswa terhadap model pembelajaran berbasis pengalaman.

Keefektifan penggunaan model pembelajaran berbasis pengalaman ditentukan berdasarkan perbandingan gain yang dinormalisasi antara kelas eksperimen dan kelas kontrol.

\section{HASIL DAN PEMBAHASAN}

\subsection{Peningkatan Pemahaman konsep}

Keefektifan penerapan model pembelajaran berbasis pengalaman untuk meningkatkan pemahaman konsep dilakukan pada materi pokok kalor dengan membandingkan nilai rata-rata gain yang dinormalisasi antara kelas eksperimen yang menggunakan model pembelajaran berbasis pengalaman dengan kelas kontrol yang menggunakan model pembelajaran konvensional. Perbandingan nilai rata-rata pretest, posttest dan gain yang dinormalisasi antara kelompok eksperimen dan kelompok kontrol ditunjukkan oleh Gambar 1. 




Gambar 1. Diagram Batang perbandingan Skor

Rata-rata Pretest, Posttest dan N-gain antara kelas eksperimen dan kelas kontrol

Berdasarkan Gambar 1 diperoleh bahwa nilai rata-rata gain yang dinormalisasi untuk kelas eksperimen ialah 0,52 dengan kategori sedang dan nilai rata-rata gain yang dinormalisasi untuk kelas kontrol ialah 0,41 dengan kategori sedang.

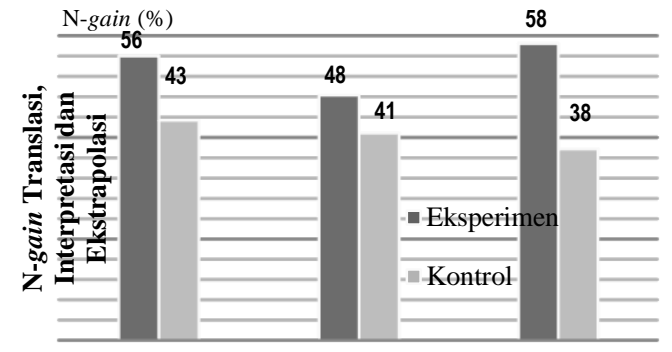

Gambar 2. Diagram Batang Perbandingan N-gain tiap aspek pemahaman konsep antara kelas ekspermen dan kelas kontrol

Gambar 2 menunjukan nilai rata-rata gain yang dinormalisasi untuk aspek translasi kelas eksperimen sebesar 0,56 dengan kategori sedang dan nilai rata-rata gain yang dinormalisasi untuk aspek translasi kelas kontrol ialah 0,43 dengan kategori sedang. Pada aspek interpretasi diperoleh nilai rata-rata gain yang dinormalisasi kelas eksperimen sebesar 0,48 dengan kategori sedang, dan untuk aspek interpretasi kelas kontrol sebesar 0,41 dengan kategori sedang. Kemudian untuk aspek ekstrapolasi diperoleh nila rata-rata gain yang dinormalisasi untuk kelas eksperimen sebesar 0,58 dengan kategori sedang dan untuk kelas kontrol sebesar 0,38. Perbandingan nilai ini secara tidak langsung menunjukkan bahwa untuk keseluruhan aspek yang ditinjau, penggunaan model pembelajaran berbasis pengalaman lebih baik dalam meningkatkan indikator translasi pemahaman konsep kalor dibandingkan dengan model pembelajaran konvensional.

\subsubsection{Pengujian Hipotesis}

Model pembelajaran berbasis pengalaman dalam meningkatkan pemahaman konsep, dianalisis berdasarkan distribusi nilai rata-rata gain yang dinormalisasi antara kelas eksperimen dan kelas kontrol.

\subsubsection{Uji Normalitas}

Uji normalitas nilai rata-rata gain yang dinormalisasi terhadap kelas eksperimen dan kontrol menggunakan software SPSS 16 yang hasilnya diperlihat pada tabel 4.1.

Tabel 2. Hasil Uji Normalitas

\begin{tabular}{|c|c|c|c|c|c|}
\hline \multicolumn{3}{|c|}{ Kelas Eksperimen } & \multicolumn{3}{|c|}{ Kelas Kontrol } \\
\hline $\mathrm{N}=$ & Mean $=5$ & $\mathrm{SD}=17$ & $\mathrm{~N}=$ & Mean $=4$ & $\mathrm{SD}=15$ \\
\hline 32 & 1,28 & 98 & 30 & 1,10 & ,44 \\
\hline Sig & $\alpha$ & $\begin{array}{c}\text { Distri } \\
\text { busi }\end{array}$ & Sig & $\alpha$ & $\begin{array}{c}\text { Distri } \\
\text { busi }\end{array}$ \\
\hline $\begin{array}{l}0,2 \\
00\end{array}$ & 0,05 & $\begin{array}{c}\text { Norm } \\
\text { al }\end{array}$ & $\begin{array}{l}0,1 \\
86\end{array}$ & 0,05 & $\begin{array}{c}\text { Norm } \\
\text { al }\end{array}$ \\
\hline
\end{tabular}

Berdasarkan uji normalitas distribusi data dengan menggunakan SPSS 16 untuk jumlah sampel 32 dan taraf kepercayaan 0,95 terhadap kelas eksperimen diperoleh sig 0,200 > 0,05. Maka data pada kelas eksperimen berdistribusi normal. Dan uji normalitas terhadap kelas kontrol dengan jumlah sampel 30 dan taraf kepercayaan 0,95 diperoleh sig 0,200>0,05. Sehingga, data pada kelas kontrol juga berdistribusi normal.

\subsubsection{Uji Homogenitas}

Uji homogenitas varians pada penelitian ini yaitu uji homogenitas varian atas rata-rata gain yang dinormalisasi antara kelas eksperimen 
dengan kelas kontrol. Untuk menguji varians kedua sampel digunakan SPSS 16 yang hasilnya diperlihatkan pada Tabel 4.2 sebagai berikut: Tabel 3 Hasil Uji Homogenitas

\begin{tabular}{ccc}
\hline Sig & A & Kesimpulan \\
\hline 0,291 & 0,05 & Homogen \\
\hline
\end{tabular}

Berdasarkan uji homogenitas rata-rata gain yang dinormalisasi dengan menggunakan SPSS 16 diperoleh nilai sig 0,291 >0,05 untuk derajat kebebasan $\mathrm{df} 1=1 \mathrm{dan} \mathrm{df} 2=60$ dengan tingkat kepercayaan 0,95. Sehingga dapat disimpulkan bahwa kedua kelompok memiliki variansi yang homogen.

\subsubsection{Uji Hipotesis}

Setelah diperoleh data peningkatan pemahaman konsep berdistribusi normal dan homogen maka selanjutnya dilakukan uji $t$ dua sampel independen menggunakan program SPSS 16 dengan taraf signifikansi $\alpha=0,05$. Berdasarkan uji tersebut diperoleh nilai signifikansi $=0,02$ yang lebih kecil dibandingkan nilai $\alpha=0,05$.

Berdasarkan uji tersebut dapat disimpulkan bahwa pembelajaran materi pokok kalor menggunakan model pembelajaran berbasis pengalaman secara signifikan dapat lebih meningkatkan pemahaman konsep siswa dibanding dengan pembelajaran konvensional. Berdasarkan analisis dari uji t dapat disimpulkan bahwa peningkatan pemahaman konsep kelas eksperimen lebih baik daripada peningkatan pemahaman konsep kelas kontrol.

1. Keterlaksanaan Pembelajaran

Pada bagian ini disajikan aktivitas peserta didik dan guru selama pembelajaran berbasis pengalaman yang diperoleh dari lembar observasi yang telah disediakan untuk setiap Rencana Pelaksanaan Pembelajaran (RPP) yang dilaksanakan selama pembelajaran dengan model pembelajaran berbasis pengalaman pada konsep kalor.

Pelaksanaan penelitian dilaksanakan selama tiga kali pertemuan. Kelas eksperimen diberi perlakuan (treatment) berupa penerapan model pembelajaran berbasis pengalaman. Sebelum dilakukan treatment, terlebih dahulu dilakukan tes awal untuk mengetahui pemahaman konsep dan keterampilan proses sains konsep kalor sebelum dilakukan treatment. Kemudian dilakukan penerapan model pembelajaran berbasis pengalaman.

Pada saat pelaksanaan pembelajaran, dilakukan observasi keterlaksanaan pembelajaran oleh satu orang observer/guru mata pelajaran IPA di sekolah tersebut. Setelah proses perlakuan selesai, kegiatan diakhiri dengan pemberian tes akhir pemahaman konsep dan keterampilan proses sains, yang dimaksudkan untuk mengetahui peningkatan pemahaman konsep dan keterampilan proses sains peserta didik setelah proses pembelajaran dilaksanakan.

Berdasarkan perhitungan menggunakan microsoft oficce exell, rata-rata persentase keterlaksanaan model pembelajaran berbasis pengalaman selama tiga kali pertemuan mencapai 95\% yang termasuk dalam kategori sangat baik sekali.

Selanjutnya, berdasarkan hasil perhitungan didapat rata-rata persentase aktivitas siswa pertemuan satu $81 \%$, pertemuan dua $83 \%$, pertemuan tiga 92\%. Secara keseluruhan persentase aktivitas siswa mempunyai rata-rata sebesar 85\% dengan kategori baik sekali.

2. Tanggapan Siswa

Untuk mengetahui tanggapan siswa terhadap pembelajaran materi kalor menggunakan pembelajaran berbasis pengalaman dilakukan dengan membagikan angket yang berisi 15 butir pernyataan yang berkaitan dengan persepsi tentang model, ketertarikan terhadap model, dan motivasi akibat model yang diterapkan. 


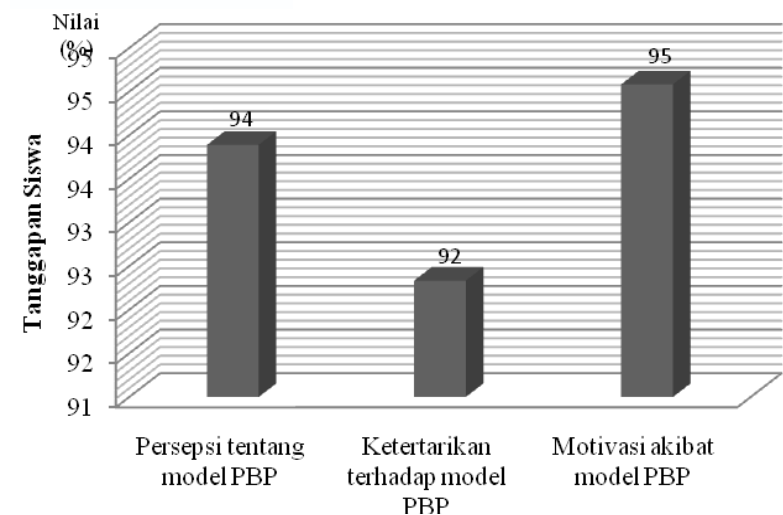

Gambar 5 Diagram Tanggapan Siswa terhadap penerapan Model Pembelajaran Berbasis

Pengalaman

Berdasarkan diagram di atas, dapat dideskripsikan bahwa hampir seluruh siswa memberikan tanggapan positif (sangat setuju dan setuju) bahwa model pembelajaran berbasis pengalaman dapat membantu siswa dalam memahami konsep-konsep fisika, tertarik dengan eksperimen yang diajarkan, dan mampu menumbuhkan motivasi belajar fisika.

\section{KESIMPULAN}

Berdasarkan hasil penelitian dan analisis data, maka dapat disimpulkan bahwa:

1. Pemahaman konsep siswa yang mendapatkan model pembelajaran berbasis pengalaman dan yang mendapatkan pembelajaran konvensional mengalami peningkatan yang termasuk kategori sedang.

2. Model pembelajaran berbasis pengalaman secara signifikan dapat lebih meningkatkan pemahaman konsep pada materi pokok kalor dibandingkan dengan model pembelajaran konvensional

3. Siswa memberikan tanggapan positif terhadap penerapan model pembelajaran berbasis pengalaman pada materi pokok kalor.

\section{DAFTAR PUSTAKA}

J Yurneti. (2002). Pembelajaran Kooperatif Sebagai Model Alternatif dalam
Pembelajaran Fisika. Jurnal Fisika HFI. B5, (0561), 1-4, 1.

Kaniawati, I. (2011). Pembelajaran Fisika Berbasis Pengalaman untuk Mengembangkan Pemahaman Konsep, Keterampilan Proses Sains dan Kemampuan Pemecahan Masalah. Bandung.

Mathematics, T. (2011). Chapter 5 TIMSS 2011 INTERNATIONAL RESULTS IN MATHEMATICS CHAPTER 5.

Ratna Wilis Dahar. (1996). Teori-teori Belajar. bandung: Penerbit Erlangga.

S.B. Djamarah. (2009). Guru dan Anak Didik dalam Interaksi Edukatif Suatu

Pendekatan Teoretis Psikologis. Jakarta: Rineka Cipta.

Sugiyono. (2009). Metodologi Penelitian Pendidikan. Bandung: Alfabeta. 